MINERALOGIA, 42, No 1: 63-72 (2011)

DOI: 10.2478/v10002-011-0007-6

www.Mineralogia.pl

MineRALOGICAL SocietY of Poland

Polskie TOWARZYSTWO MINERALOGICZNE

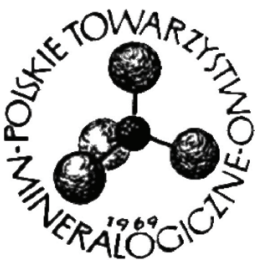

Original paper

\title{
Geochemistry of waters and bottom sediments in landslide lakes in Babiogórski National Park
}

\author{
Dariusz SALA ${ }^{1 *}$, Grzegorz RZEPA ${ }^{1}$ \\ ${ }^{1}$ AGH University of Science and Technology; Faculty of Geology, Geophysics and Environmental Protection; \\ Department of Mineralogy, Petrography and Geochemistry, al. Mickiewicza 30, 30-059 Kraków, Poland; \\ e-mail: saladariusz@wp.pl \\ * Corresponding author
}

Received: March 31, 2010

Received in revised form: October 12, 2010

Accepted: October 29, 2010

Available online: November 20, 2010

Abstract. The aim of this work was to assess the contamination of the landslide lakes located within Babiogórski National Park. For this purpose, samples of water and bottom sediment from 12 lakes were collected. Chemical analyses of the waters (including main cation and anion concentrations, trace-metal levels and selected physicochemical parameters) and of the sediments (including heavy metals) were performed. The waters are acidic to neutral and are characterized by low mineralization. Concentrations of trace elements are commonly low. Elevated levels of $\mathrm{Fe}, \mathrm{Mn}$ and $\mathrm{Al}$ are probably related to natural geochemical processes. The sediments are strongly contaminated by $\mathrm{Cd}$, whereas other trace metals levels are at their hydrogeochemical background. The high level of $\mathrm{Cd}$ contamination is most probably related to long-range industrial emissions.

Key-words: bottom sediments, water, trace elements, Babiogórski National Park

\section{Introduction}

Babiogórski National Park (BNP) with an area of 3391.55 ha is situated in the eastern part of the Beskid Żywiecki in the Polish part of the Western Outer Carpathians. It was founded in 1954 to protect local ecosystems, namely, the Carpathian spruce forests, the dwarf mountain pine belt and alpine meadows. In 1977, the BNP was assigned to the 
Biosphere Reserve network and was integrated with the UNESCO program "Man and Biosphere" as one of the first protected areas in Poland (Omylak 2004).

The Babia Góra massif (1725 m above sea level) comprises Upper CretaceousPaleogene flysch sediments with the Magura sandstone in the uppermost parts. The latter are represented by thick layers of sandstones with thin intercalations of mudstone and shale. Quaternary sediments, covering a significant part of the area, occur in Pleistocene and Holocene terraces running along the valleys of streams and rivers associated with alluvial cones, as colluvia of numerous landslides and as block-fields spread over the northern slope of Babia Góra Mt. (Alexandrowicz 2004).

\section{Materials and methods}

The Polish part of the BNP comprises about 19 natural ponds that were formed mostly by landslides. The ponds are located on the forested northern slope of the Babia Góra Mt. (lower- and upper forest belts). Only three ponds on the highest part of the mountain are situated in the dwarf mountain pine belt. These small lakes $\left(<\right.$ ca $\left.450 \mathrm{~m}^{2}\right)$ are usually dry in summer. Only the largest may persist all year round (Sala, Rzepa 2008). In spite of nearly two hundred years of scientific research in the area of the Babia Góra Mt., these natural reservoirs are still relatively poorly recognized.

The goal of this study was to assess the contamination of the landslide lakes within the BNP and to evaluate possible pollution sources. The water and bottom sediment samples were collected from 12 lakes (1-12 on Fig. 1) during the summers of 2007 and 2008. Electrolytic conductivity (EC), $\mathrm{pH}$ and temperature were measured in situ. Chemical analyses (Standard Methods..., 1999) of the water included determinations of major cations $\left(\mathrm{Ca}^{2+}, \mathrm{Mg}^{2+}, \mathrm{Na}^{+}, \mathrm{K}^{+}\right)$and anions $\left(\mathrm{HCO}_{3}{ }^{-}, \mathrm{Cl}^{-}, \mathrm{SO}_{4}{ }^{2-}, \mathrm{PO}_{4}{ }^{3-}\right)$ as well as trace metals $(\mathrm{Al}, \mathrm{Cd}$, $\mathrm{Cu}, \mathrm{Fe}, \mathrm{Mn}, \mathrm{Pb}, \mathrm{Zn})$. Calcium and magnesium concentrations were determined by EDTA (titrimetric method).

Sodium and potassium were analyzed by flame emission spectrometry (Philips PU9100X spectrometer). Bicarbonate- and chloride contents were evaluated by titration (hydrochloric acid- and argentometric methods, respectively) and sulphate and phosphate by colorimetry (turbidimetric- and ascorbic-acid methods, respectively (Hitachi U-1800 spectrometer). Trace-element concentrations were determined by ICP-MS (Perkin Elmer, Elan 6100 spectrometer). In addition, selected physicochemical parameters such as color, turbidity, odor, BOD (biological oxygen demand) and COD (chemical oxygen demand) were measured. Bottom-sediment samples were analyzed for trace metals $(\mathrm{Cd}, \mathrm{Cr}, \mathrm{Cu}, \mathrm{Pb}$, Zn) by AAS using the procedure developed by the U.S. Environmental Protection Agency for heavy metals in soils, sediments and sludges (Soon, Abboud 1993). Micromorphological observations and chemical analyses were carried out using a Scanning Electron Microscope (FEI Quanta 200F) with Energy Dispersive X-Ray Spectrometer SEM/EDS. 


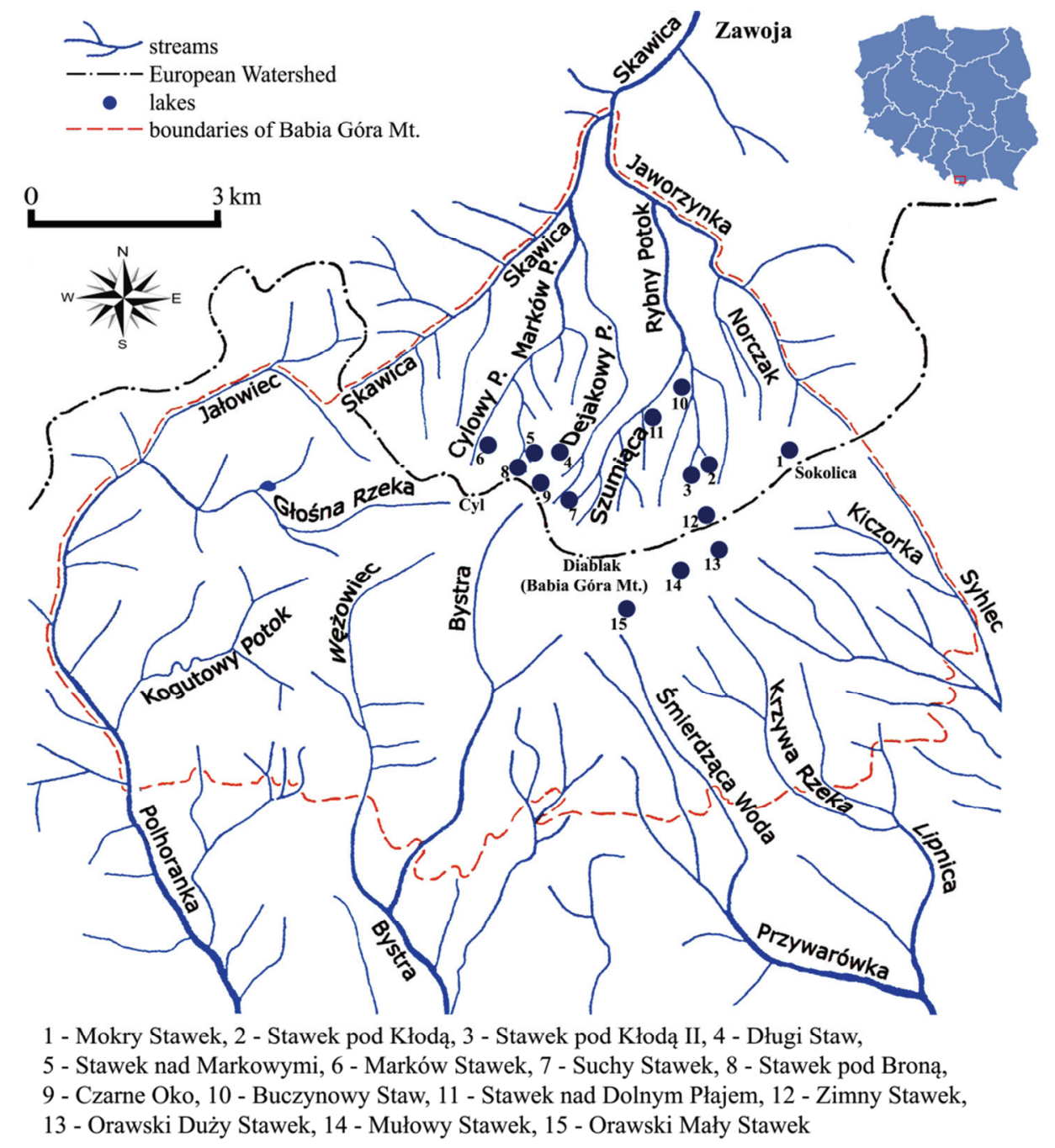

Fig. 1. Location of landslide lakes (Lajczak 2005, modified).

\section{Results and discussion}

Springs in the BNP supplied from groundwater reservoirs in the Magura sandstone are characterized by low mineralization $(30-208 \mu \mathrm{S} / \mathrm{cm})$ and low general hardness $\left(1.0-6.7^{\circ} \mathrm{N}\right)$ (Lajczak 2004a). These parameters are cyclic, reaching maximum values in autumn and winter and minimum values during the spring thaw (Łajczak 1998). Increased mineralization is noted when the water flows through mudstones and shales (Łajczak 2004a).

Waters from ponds are acidic to nearly neutral ( $\mathrm{pH}$ 4.1-7.4) with low mineralization (EC values range from $22-257 \mu \mathrm{S} / \mathrm{cm}$ ) (Table 1). The high COD (5.3-238.2 $\mathrm{mg} \mathrm{O}_{2} / \mathrm{L}$ ) and BOD (0.02-4.82 $\mathrm{mg} \mathrm{O}_{2} / \mathrm{L}$ ) indicate high amounts of organic matter (Sala, Rzepa 2008). 
Physicochemical parameters of the water samples (n.d. - not determined).

\begin{tabular}{lllllllll}
\hline $\begin{array}{l}\text { Statistical } \\
\text { parameters }\end{array}$ & \multicolumn{2}{l}{ Minimum } & \multicolumn{3}{c}{ Median } & \multicolumn{2}{c}{ Arithmetic mean } & \multicolumn{2}{l}{ Maximum } \\
& 2007 & 2008 & 2007 & 2008 & 2007 & 2008 & 2007 & 2008 \\
\hline $\mathrm{pH}$ & 4.08 & 3.94 & 6.25 & 6.73 & 5.84 & 6.00 & 7.44 & 6.86 \\
$\mathrm{EC}[\mu \mathrm{S} / \mathrm{cm}]$ & 22 & 20 & 88 & 109 & 96 & 95 & 257 & 177 \\
Temperature $\left[{ }^{\circ} \mathrm{C}\right]$ & 9.0 & 11.0 & 13.0 & 15.0 & 13.0 & 14.7 & 17.0 & 17.5 \\
Color $[\mathrm{mg} \mathrm{Pt} / \mathrm{L}]$ & 6.2 & 6.2 & 10.2 & 10.2 & 68.9 & 56.3 & 234.0 & 240.0 \\
Turbidity $[\mathrm{NTU}]$ & 0.26 & 1.15 & 2.06 & 1.92 & 11.74 & 1.90 & 130.80 & 3.12 \\
BOD $\left[\mathrm{mg} \mathrm{O}_{2} / \mathrm{L}\right]$ & 0.02 & n.d. & 0.38 & n.d. & 0.72 & n.d. & 4.82 & n.d. \\
COD $\left[\mathrm{mg} \mathrm{O}_{2} / \mathrm{L}\right]$ & 5.30 & 8.16 & 16.00 & 15.51 & 54.35 & 35.10 & 238.20 & 115.92 \\
\hline
\end{tabular}

The lowest $\mathrm{pH}$ values $(\sim 5.5)$ are recorded in the ponds located within small peat areas (e.g., the ponds at Stawek pod Kłodą, Zimny Stawek and Stawek nad Markowymi). Interestingly, these lakes are also characterized by rather low EC $(20-80 \mu \mathrm{S} / \mathrm{cm}$; Sala, Rzepa 2008). The dominant role of organic matter in the chemical composition of these waters is emphasized by their intense color $(<240 \mathrm{mg} \mathrm{Pt} / \mathrm{L})$, organic odor and high COD $\left(\sim 240 \mathrm{mg} \mathrm{O}_{2} / \mathrm{L}\right)$. High turbidity $(<130 \mathrm{NTU})$ and biochemical oxygen demands $(<4.82 \mathrm{mg}$ $\left.\mathrm{O}_{2} / \mathrm{L}\right)$ are also typical for these ponds.

The chemical composition of larger ponds (e.g., the ponds at Mokry Stawek and Długi Stawek) is quite different being less acidic and showing higher $(>100 \mu \mathrm{S} / \mathrm{cm}) \mathrm{EC}$ values. Low color (usually $<10 \mathrm{mg} \mathrm{Pt} / \mathrm{L})$, low turbidity $(<2 \mathrm{NTU})$ and low COD values $(<20 \mathrm{mg}$ $\mathrm{O}_{2} / \mathrm{L}$ ) indicate rather low organic matter contents.

The concentrations of major ionic constituents of the water samples were plotted on a Piper diagram (Fig. 2) which consists of two triangles and a diamond (Appelo, Postma 2005). The diamond shaped field between the two triangles is used to represent the composition of water with respect to both cations $\left(\mathrm{Ca}^{2+}, \mathrm{Mg}^{2+}\right.$ and $\left.\mathrm{Na}^{+}+\mathrm{K}^{+}\right)$and anions $\left(\mathrm{HCO}_{3}{ }^{-}, \mathrm{SO}_{4}{ }^{2-}\right.$ and $\left.\mathrm{Cl}^{-}\right)$. The points for the cations and the anions are plotted on the appropriate triangle diagrams. 


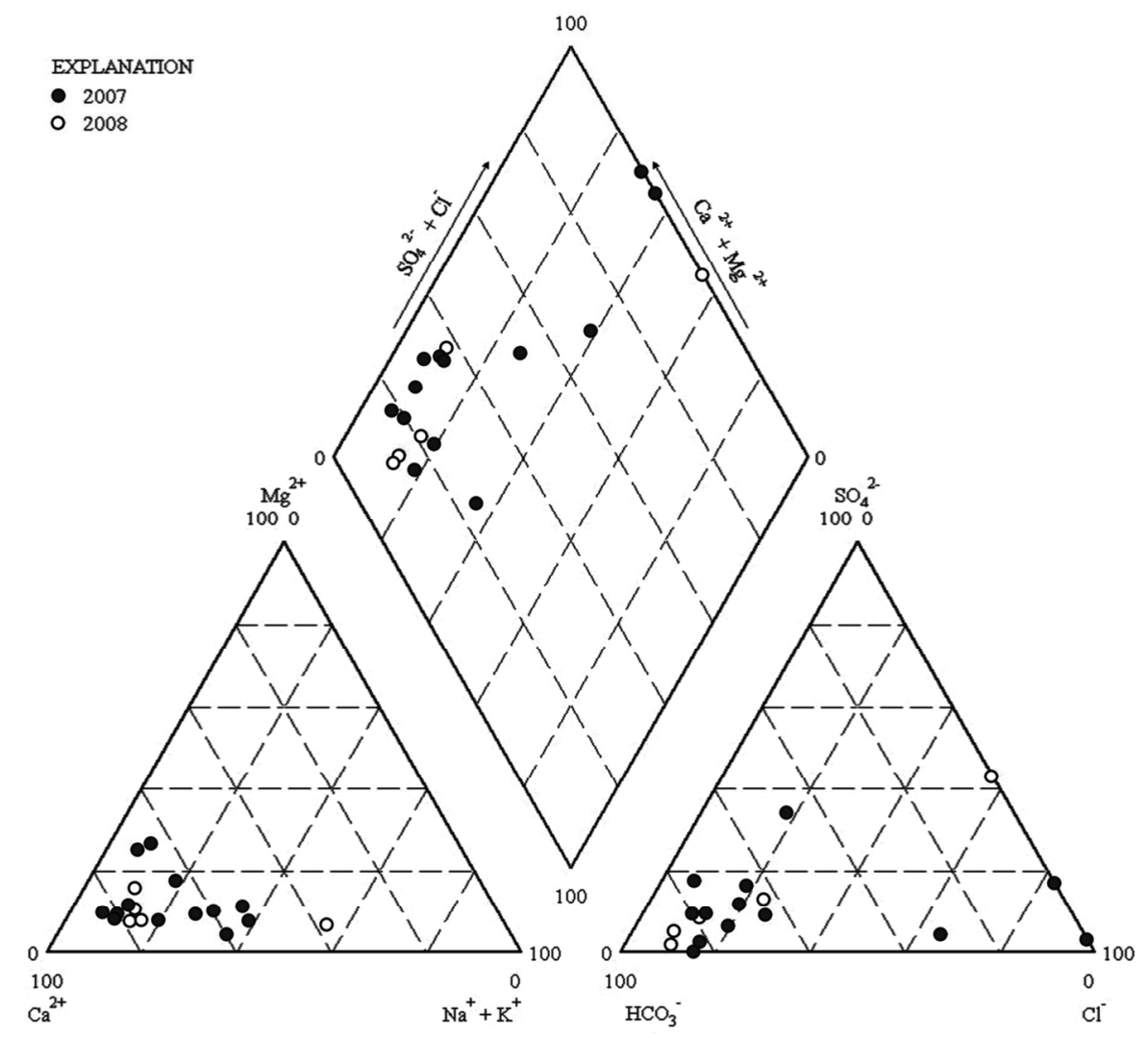

Fig. 2. Piper diagram of the water samples studied.

Waters from the ponds (Table 2) are usually of calcium-bicarbonate type or calciummagnesium-bicarbonate type, with $\mathrm{Ca}^{2+}$ and $\mathrm{HCO}_{3}{ }^{-}$concentrations reaching up to $40 \%$ mval. Only the most acid lakes are filled with bicarbonate-free water of calcium-chloride type. Concentrations of minor cations and anions are low (Table 2).

The trace-metal concentrations ( $\mathrm{Al}, \mathrm{Cd}, \mathrm{Cu}, \mathrm{Fe}, \mathrm{Mn}, \mathrm{Pb}, \mathrm{Zn})$ in the lake waters serve as a basis for the evaluation of environmental pollution in the BNP. The distribution of these elements is summarized in Table 3. The average concentrations of $\mathrm{Cd}(0.215 \mu \mathrm{g} / \mathrm{L}), \mathrm{Cu}$ $(1.64 \mu \mathrm{g} / \mathrm{L}), \mathrm{Zn}(18.2 \mu \mathrm{g} / \mathrm{L})$ and $\mathrm{Pb}(4.94 \mu \mathrm{g} / \mathrm{L})$ in the waters are low, but some lakes (e.g., the ponds at Stawek pod Kłodą, Stawek pod Kłodą II and Stawek nad Markowymi) show elevated amounts of $\mathrm{Cd}$ and $\mathrm{Pb}$ that exceed admissible concentrations in surface water (Table 3). These lakes are also characterized by quite high $\mathrm{Mn}(<300 \mu \mathrm{g} / \mathrm{L})$, Al $(<900 \mu \mathrm{g} / \mathrm{L})$ and $\mathrm{Fe}(<1600 \mu \mathrm{g} / \mathrm{L})$ (Table 3). It is noteworthy that the highest concentrations of trace elements occur in the organic-rich ponds with the lowest $\mathrm{pH}$ values. This correlation suggests that the elevated trace-metal levels are related to natural geochemical processes, probably leaching from the bottom sediments by acid waters rich in organic complexing agents. The fact that the neutral- or slightly-alkaline lakes poor in organic matter show low metal contents supports this assumption. 
Selected statistical parameters for the major cations and anions $[\mathrm{mg} / \mathrm{L}]$.

\begin{tabular}{|c|c|c|c|c|c|c|c|c|}
\hline \multirow[t]{2}{*}{ Ion } & \multicolumn{2}{|c|}{ Minimum } & \multicolumn{2}{|c|}{ Median } & \multicolumn{2}{|c|}{ Arithmetic mean } & \multicolumn{2}{|c|}{ Maximum } \\
\hline & 2007 & 2008 & 2007 & 2008 & 2007 & 2008 & 2007 & 2008 \\
\hline $\mathrm{Ca}^{2+}$ & 1.60 & 1.60 & 9.60 & 11.04 & 9.26 & 8.83 & 25.20 & 17.60 \\
\hline $\mathrm{Mg}^{2+}$ & 0.14 & 0.29 & 0.76 & 1.06 & 1.22 & 1.09 & 5.53 & 2.40 \\
\hline $\mathrm{Na}^{+}$ & 0.22 & 0.17 & 1.00 & 1.14 & 1.16 & 102 & 2.24 & 2.12 \\
\hline $\mathrm{K}^{+}$ & 0.35 & 0.23 & 0.94 & 0.97 & 1.14 & 0.86 & 3.01 & 1.24 \\
\hline $\mathrm{HCO}_{3}^{-}$ & 0.00 & 0.00 & 2.20 & 3.51 & 27.68 & 25.63 & 90.00 & 57.96 \\
\hline $\mathrm{Cl}^{-}$ & 1.05 & 2.35 & 4.80 & 3.50 & 5.18 & 4.11 & 9.80 & 6.65 \\
\hline $\mathrm{SO}_{4}^{2-}$ & 0.00 & 1.20 & 3.48 & 2.01 & 2.75 & 2.03 & 5.73 & 3.29 \\
\hline $\mathrm{PO}_{4}{ }^{3-}$ & 0.02 & 0.01 & 0.05 & 0.06 & 0.09 & 0.07 & 0.26 & 0.16 \\
\hline
\end{tabular}

The average concentration of trace elements in waters $[\mu \mathrm{g} / \mathrm{L}]$.

\begin{tabular}{|c|c|c|c|c|c|c|c|}
\hline Pond's name & $\mathrm{Zn}$ & $\mathrm{Fe}$ & $\mathrm{Mn}$ & $\mathrm{Al}$ & $\mathrm{Cu}$ & $\mathrm{Pb}$ & $\mathrm{Cd}$ \\
\hline The Mokry Stawek & 13.0 & 48.0 & 16.0 & 31.6 & 1.14 & 1.12 & 0.041 \\
\hline The Stawek pod Kłodą & 47.0 & 554 & 55.0 & 244 & 1.42 & 12.60 & 0.565 \\
\hline The Stawek pod Kłodą II & 37.0 & 1602 & 144 & 648 & 2.30 & 14.50 & 0.617 \\
\hline The Długi Staw & 11.0 & 13.0 & 20.0 & 20.6 & 0.66 & 1.35 & 0.123 \\
\hline The Stawek nad Markowymi & 19.0 & 570 & 20.0 & 903 & 7.54 & 17.60 & 0.482 \\
\hline The Marków Stawek & 11.0 & 200 & 13.0 & 159 & 1.08 & 3.53 & 0.069 \\
\hline The Suchy Stawek & 14.0 & 80.0 & 17.0 & 30.6 & 0.42 & 1.09 & 0.037 \\
\hline The Stawek pod Broną & 13.0 & 68.0 & 28.0 & 31.8 & 0.50 & 1.55 & 0.042 \\
\hline The Czarne Oko & 25.0 & 684 & 202 & 429 & 1.94 & 4.25 & 0.314 \\
\hline The Buczynowy Staw & 14.0 & 392 & 53.0 & 75.2 & 1.71 & 2.65 & 0.164 \\
\hline The Stawek nad Dolnym Płajem & 14.0 & 230 & 39.0 & 75.7 & 0.67 & 0.94 & 0.161 \\
\hline The Zimny Stawek & 7.0 & 156 & 300 & 83.0 & 0.85 & 2.66 & 0.121 \\
\hline admissible concentration $^{1}$ & 1000 & - & - & 400 & 50 & 7.2 & 0.45 \\
\hline admissible concentration $^{2}$ & 300 & 100 & 50 & 100 & 20 & 10 & 0.5 \\
\hline $\begin{array}{l}\text { typical concentration in } \\
\text { uncontaminated water }\end{array}$ & 10 & $10-1400$ & 6 & 64 & 6 & 0.2 & 0.02 \\
\hline
\end{tabular}

${ }^{1}$ according to Rozporządzenie..., 2008

2 according to Rozporządzenie..., 2004

${ }^{3}$ according to Kabata-Pendias, Pendias 1999 
The trace-metal concentrations in the bottom sediments are usually low also. However, they vary depending on the sediment type and lake location. The concentrations in $\mathrm{mg} / \mathrm{kg}$ are as follows: $\mathrm{Zn}-9.93-64.65, \mathrm{~Pb}-6.08-21.88, \mathrm{Cu}-1.68-6.53$ and $\mathrm{Cr}-0.19$ $4.54 \mathrm{mg} / \mathrm{kg}$ (Table 4). Only Cd contents are elevated, ranging from $1.12-25.94 \mathrm{mg} / \mathrm{kg}$ with an average of $10.57 \mathrm{mg} / \mathrm{kg}$ (Sala, Rzepa 2009). These values exceed geochemical background values $(<1 \mathrm{mg} / \mathrm{kg} \mathrm{Cd})$ for the region (Lis, Pasieczna 1995). The largest amounts of Cd occur in the Stawek pod Kłoda pond $(25.71 \mathrm{mg} / \mathrm{kg})$, the Buczynowy Staw pond, the Stawek nad Markowymi pond $(\sim 15.53 \mathrm{mg} / \mathrm{kg})$, and in the Zimny Stawek pond $(17.92 \mathrm{mg} / \mathrm{kg})$, all of which have bottom sediments rich in organic matter. A distinct relationship between the $\mathrm{Cd}$ contents in the sediments and its concentration in the waters may suggest that the raised levels of $\mathrm{Cd}$ in the waters resulted from interactions with the sediments rather than from atmospheric deposition.

Comparison of the trace-metal contents (except $\mathrm{Cd}$ ) with the LAWA classification (1998; Table 5) reveals that all of the bottom sediment samples may be classified as belonging to the I purity class. However, more than half of the samples are strongly contaminated with $\mathrm{Cd}$ and belong to the IV purity class.

TABLE 4

The average concentration of trace elements in bottom sediments $[\mathrm{mg} / \mathrm{kg}](\mathrm{O}$ - organic sediment, $\mathrm{M}$ - mineral sediment).

\begin{tabular}{llllll}
\hline Pond's name & $\mathrm{Cd}$ & $\mathrm{Cr}$ & $\mathrm{Cu}$ & $\mathrm{Pb}$ & $\mathrm{Zn}$ \\
\hline The Mokry Stawek & 2.72 & 4.54 & 2.74 & 9.64 & 48.68 \\
The Stawek pod Kłodą & 25.71 & 0.28 & 6.53 & 15.63 & 64.65 \\
The Stawek pod Kłodą II & 18.59 & 1.57 & 3.53 & 11.28 & 14.16 \\
The Długi Stawek & 1.20 & 4.07 & 2.06 & 14.06 & 13.66 \\
The Stawek nad Markowymi & 15.53 & 0.74 & 5.56 & 21.88 & 45.88 \\
The Marków Stawek & 11.16 & 4.17 & 3.76 & 10.07 & 13.43 \\
The Suchy Stawek & 7.12 & 3.80 & 3.35 & 13.19 & 62.74 \\
The Stawek pod Broną & 2.66 & 3.52 & 4.56 & 12.67 & 45.41 \\
The Czarne Oko & 5.45 & 4.35 & 2.38 & 6.08 & 9.93 \\
The Buczynowy Staw & 15.40 & 1.20 & 3.15 & 10.76 & 48.71 \\
The Stawek nad Dolnym Płajem & 4.60 & 3.43 & 2.97 & 9.46 & 51.77 \\
The Zimny Stawek (M) & 6.81 & 3.80 & 1.68 & 7.99 & 53.08 \\
The Zimny Stawek (O) & 17.92 & 3.61 & 2.62 & 12.85 & 45.38 \\
\hline
\end{tabular}


Permissible value of trace metals concentration in sediment and suspended matter according to LAWA classification (Irmer 1997, LAWA 1998).

\begin{tabular}{|c|c|c|c|c|c|c|c|}
\hline \multirow[t]{2}{*}{ Metal } & \multicolumn{7}{|c|}{ Purity classes of sediment and suspended matter $[\mathrm{mg} / \mathrm{kg}]$} \\
\hline & I & I-II & II $^{*}$ & II-III & III & III-IV & IV \\
\hline $\mathrm{Cd}$ & $\leq 0.3$ & $\leq 0.6$ & $\leq 1.2$ & $\leq 2.4$ & $\leq 4.8$ & $\leq 9.6$ & $>9.6$ \\
\hline $\mathrm{Cr}$ & $\leq 80$ & $\leq 160$ & $\leq 320$ & $\leq 640$ & $\leq 1280$ & $\leq 2560$ & $>2560$ \\
\hline $\mathrm{Cu}$ & $\leq 20$ & $\leq 40$ & $\leq 80$ & $\leq 160$ & $\leq 320$ & $\leq 640$ & $>640$ \\
\hline $\mathrm{Pb}$ & $\leq 25$ & $\leq 50$ & $\leq 100$ & $\leq 200$ & $\leq 400$ & $\leq 800$ & $>800$ \\
\hline $\mathrm{Zn}$ & $\leq 100$ & $\leq 200$ & $\leq 400$ & $\leq 800$ & $\leq 1600$ & $\leq 3200$ & $>3200$ \\
\hline
\end{tabular}

* - recommended permissible value of pollution

Explanation of purity classes: I class - uncontaminated, I-II class - uncontaminated to moderately contaminated, II class - moderately contaminated, II-III class - moderately to strongly contaminated, III class - strongly contaminated, III-IV class - strongly to very strongly contaminated, IV class very strongly contaminated

The SEM observations and the EDS analyses show that the bottom sediments are composed mainly of organic matter and detrital minerals (quartz and feldspars). The sediments also contain small (up to several $\mu \mathrm{m}$ ) spherical particles that are probably of industrial origin. Particles with smooth surfaces and of aluminosilicate composition presumably reflect the combustion of fuels (Fig. 3). Those with rough surfaces (Fig. 4) and mostly iron-oxide compositions likely relate to emission from metallurgic plants.

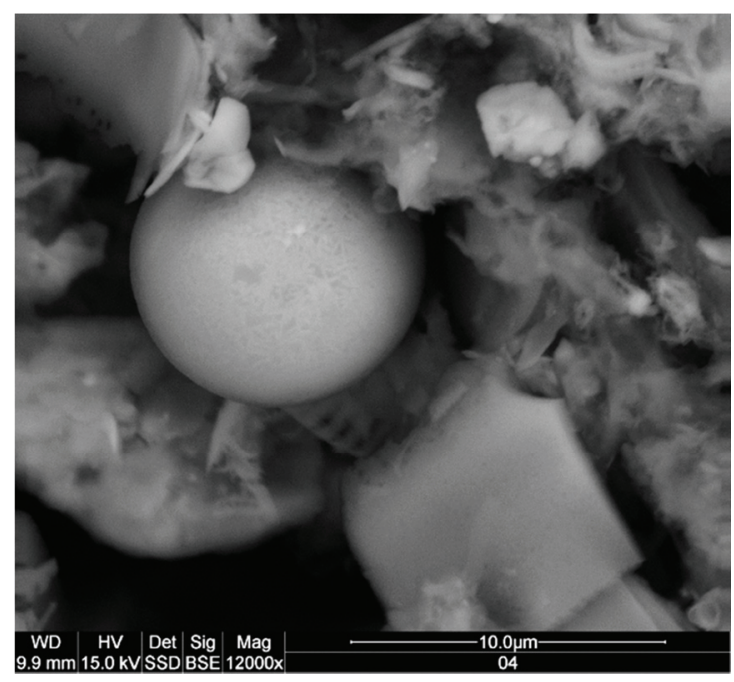

Fig. 3. Spherical alumosilicate particle probably of anthropogenic origin. BSE image. 


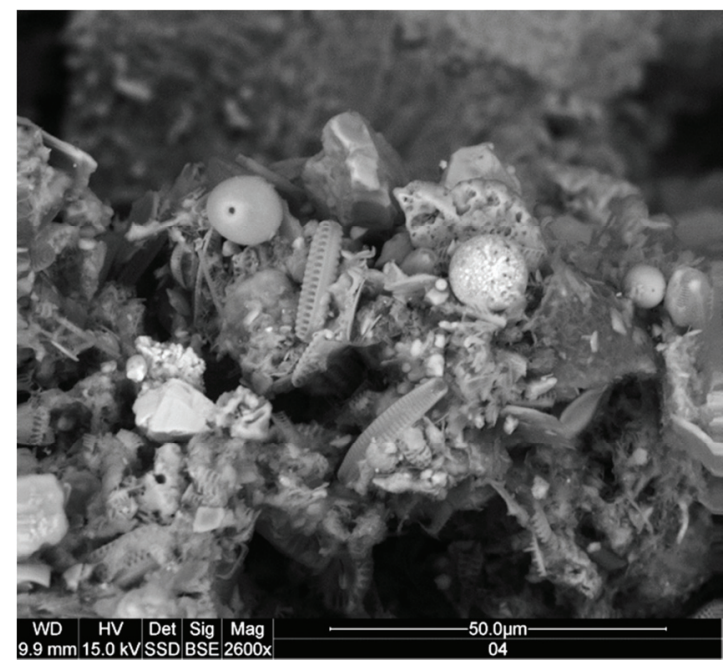

Fig. 4. Spherical iron oxide within organic-mineral matrix. BSE image.

\section{Conclusions}

The aim of this study was to assess the degree of pollution of water reservoirs in Babiogórski National Park. The ponds are acidic to neutral $(\mathrm{pH} 4.1-7.4)$ and weakly mineralized with electrolytic conductivity of $22-257 \mu \mathrm{S} / \mathrm{cm}$. They usually represent the calcium-bicarbonate type. Water samples are not contaminated by trace elements. Elevated concentrations of $\mathrm{Fe}, \mathrm{Mn}$ and $\mathrm{Al}$ are the result of natural geochemical processes and are typical for natural acid waters. Trace-metal concentrations in the bottom sediments are usually low, but vary with sediment type and lake location. Only cadmium contents are elevated, clearly exceeding background. Some previous studies (e.g., Grodzińska 1978) reported high $\mathrm{Cd}$ and $\mathrm{Pb}$ contamination levels in soils and mosses from the BNP suggesting that the pollution was probably caused by emissions from the Upper Silesian- and Ostrava industrial districts. This conclusion may be supported by the presence of industrial dust particles in the bottom sediments. However, the fact that the snowpack from the BNP is not polluted by Cd and other heavy metals (Eajczak 2004b) indicates a limited supply of this airborne element in recent years. Thus, the BNP is currently less vulnerable to anthropopression than previously.

Acknowledgements. The study was supported by AGH-UST project no. 18.18.140.174. The authors are grateful to the anonymous reviewers for helpful comments which greatly improved the manuscript.

\section{References}

Appelo, C.A.J., \& Postma, D. (2005). Geochemistry, groundwater and pollution ( $2^{\text {nd }}$ ed). London: Balkema.

Alexandrowicz, S.W. (2004). Outlines of geology of the Babia Góra range. In B.W. Wołoszyn, A. Jaworski,

J. Szwagrzyk (Eds), The Nature of the Babiogórski National Park. Monograph (pp. 87-107). Kraków:

Komitet Ochrony Przyrody PAN, Babiogórski Park Narodowy (in Polish). 
Grodzińska, K. (1978). Mosses as bioindicators of heavy metal pollution in Polish national parks. Water, Air, and Soil Pollution 9, 83-97.

Irmer, U. (1997). Bedeutung Von Hintergrundwerten für Qualitätsanforderung an Oberflä- chenwässern. Bewertung der Ergebnisse aus der Elbeschadstof-forschung. Geesthacht, 36-40.

Kabata-Pendias, A., \& Pendias, H. (1999). Biogeochemia pierwiastków śladowych (2 ${ }^{\text {nd }}$ ed). Warszawa: Wydawnictwo Naukowe PWN (in Polish).

LAWA - Landesarbeitsgemeinschaft Wasser (1998). Beurteilung der Wasserbeschchaffenheit von Fließgewässern in der Bundesrepublik Deutschland - chemische Gewässergüte-klassifikation. Zielvorgaben zum Schutz oberirdischer Binnengewässer. Band 2, Berlin, 10, 26.

Lis, J., \& Pasieczna, A. (1995). Geochemical Atlas of Poland 1:2 500 000. The Polish Geological Institute, Warszawa.

Łajczak, A. (1998). Charakterystyka hydrograficzna, zasoby wodne, zagrożenie wód i wykonanie szczegółowej mapy hydrograficznej Babiogórskiego Parku Narodowego. Zawoja: Plan ochrony Babiogórskiego Parku Narodowego (in Polish).

Łajczak, A. (2004a). Waters of Mt Babia Góra. In B.W. Wołoszyn, A. Jaworski, J. Szwagrzyk (Eds), The Nature of the Babiogórski National Park. Monograph (pp. 153-177). Kraków: Komitet Ochrony Przyrody PAN, Babiogórski Park Narodowy (in Polish).

Łajczak, A. (2004b). Snow cover of Mt. Babia Góra. In B.W. Wołoszyn, A. Jaworski, J. Szwagrzyk (Eds), The Nature of the Babiogórski National Park. Monograph (pp. 179-196). Kraków: Komitet Ochrony Przyrody PAN, Babiogórski Park Narodowy (in Polish).

Łajczak, A. (2005). Inanimate nature. In D. Ptaszycka-Jackowska (Ed.). Światy Babiej Góry (pp. 15-39). Zawoja: Babiogórski Park Narodowy (in Polish).

Omylak, J. (2004). The Babiogórski National Park's 50 $0^{\text {th }}$ anniversary. In B.W. Wołoszyn, A. Jaworski, J. Szwagrzyk (Eds), The Nature of the Babiogórski National Park. Monograph (pp. 29-37). Kraków: Komitet Ochrony Przyrody PAN, Babiogórski Park Narodowy (in Polish).

Rozporządzenie Ministra Środowiska z dnia 20 sierpnia 2008 r. w sprawie sposobu klasyfikacji stanu jednolitych części wód powierzchniowych. Dz. U. 162, 1008 (in Polish).

Rozporządzenie Ministra Środowiska z dnia 11 lutego 2004 r. w sprawie klasyfikacji dla prezentowania stanu wód powierzchniowych $i$ podziemnych, sposobu prowadzenia monitoringu oraz sposobu interpretacji wyników i prezentacji stanu tych wód. Dz. U. 32, 284 (in Polish).

Sala, D., \& Rzepa, G. (2008). Preliminary results of geochemical investigations of landslide lakes in the Babia Góra National Park. Mineralia Slovaca (40), 271.

Sala, D., \& Rzepa, G. (2009). The evaluation of contamination of landslide lakes in the Babia Góra National Park. Mineralia Slovaca (41), 368.

Soon, Y.K., \& Abboud, S. (1993). Cadmium, chromium, lead, and nickel. In Carter M.R. (Ed.) Soil Sampling and Methods of Analysis (pp. 101-108). Canadian Society of Soil Science: Lewis Publishers.

Standard Methods for the Examination of Water and Wastewater, $20^{\text {th }}$ edition (1999). American Public Health Association, Washington. 